\title{
Effective Decolourization of Textile Azo Dyes by a Novel Bacterial Isolate Lysinibacillus SI 01 through Sequential Aerobic - Microaerophilic Process
}

\author{
T. Muruganantham and S. Senthil Kumar* \\ Geobiotechnology Lab, PG and Research Department of Biotechnology, \\ National College (Autonomous), Tiruchirappalli-620001, Tamil Nadu, India \\ *Corresponding author
}

Keywords

Azo dyes, aerobic, microaerophilic condition, autochthonous bacterium, Lysinibacillus, Reactive Yellow 180, Reactive Red 180, Reactive Red 198, Red RR.

\section{Article Info}

Accepted:

28 September 2016

Available Online:

10 October 2016

\section{A B S T R A C T}

Textile effluent polluted soil samples collected from the contaminated sites of Common Effluent Treatment Plant (CETP), Perundurai, Tamil Nadu, India were screened for isolation of potential bacteria capable of decolorizing commonly used textile azo dyes. A novel bacterium, designated as 'Soil Isolate 01' (SI 01) isolated from the contaminated site was able to efficiently decolourize all the chosen four azo dyes (Reactive Yellow 180, Reactive Red 180, Reactive Red 198 and Red RR) under optimized aerobic - microaerophilic condition in nutrient broth with $\mathrm{pH} 8$ at $37^{\circ} \mathrm{C}$ and a dye concentration of $100 \mathrm{mg} . \mathrm{l}^{-1}$ with decolourization percentage $>85 \%$ in all the four dyes at $48 \mathrm{hrs}$. The biodegradation of the four azo dyes was monitored by UV-Vis analysis. Experiments revealed that the autochthonous bacterium SI 01 decolorized all the four azo dyes in such a way that its absorption peaks in the visible range disappeared indicating molecular re-arrangement of the dye structure. Scanning Electron Microscopic (SEM) analysis and Live versus inactivated cells studies proved that only live bacterial cells were able to decolorize the dye whereas inactivated cells could not is an evident that decolorization was not due to physical adsorption.

\section{Introduction}

Textile industries generate large volumes of contaminated wastewater, which leads to a serious problem for the natural ecosystem (Manai et al., 2016). The toxic effects of textile industrial wastewater are mainly due to the presence of mixture of dye molecules (Verma et al., 2012). It was quantified that more than 80,000 tons/year of dyes are used in textile dyeing process, which needs 70$150 \mathrm{dm}^{3}$ of water. It has been reported that the textile industry requires about $40 \mathrm{~g}$ of dyes for one kilogram of cotton (MendezMartineza et al., 2012). Azo dyes are one of the largest classes of synthetic dyes, which are widely used in the wet process of the color industry (Yu et al., 2015). Due to the presence of one or more azo bonds $(-\mathrm{N}=\mathrm{N}-)$ and aromatic rings in its chemical structure, it is toxic and resistant to degradation (Xu et al., 2007). As a result the release of these dyes without treatment into the environment leads to inimical impact on the aquatic ecosystem. Most of the dyes are reported as 
carcinogenic to humans (Tan et al., 2016). Therefore, azo dye containing textile wastewater should be treated before discharge into the environment. Numerous physico-chemical and biological methods have been widely used to treat textile wastewater containing azo dyes (Khouni et al., 2011). However, the physical and chemical treatments have drawbacks due to the high cost involved and release of hazardous secondary pollutants (Saratale et al., 2009a). On the contrary, bioremediation offers a cheaper and more environmentally friendly alternative method for the treatment of textile wastewater containing azo dyes (Jadhav et al., 2010). Several studies have been reported, different microorganisms such as Bacteria ( $\mathrm{Yu}$ et al., 2015), Yeast (Waghmode et al., 2011), and Fungi (Parshetti et al., 2007) are involved in the subject of color removal; in the mechanism of bioadsorption, biotransformation or degradation. The effectiveness of microbial decolorization depends on the adaptability and the activity of selected microorganisms. The mechanism of microbial degradation of azo dyes involves the reductive cleavage of azo bonds $(-\mathrm{N}=\mathrm{N}-)$ with the help of azoreductase under anaerobic conditions resulted into the formation of colorless solutions. The resulting intermediate metabolites (e.g., aromatic amines) are further degraded aerobically or anaerobically (Chang et al., 2000). In the present study we focused our attention on the isolation of potential dye-decolourizing bacteria from contaminated soil of the Common Effluent Treatment Plant (CETP), Perundurai, Tamil Nadu, India and reporting a novel autochthonous bacterium named Soil Isolate 01(SI 01) having significant decolourizing ability on several different commonly used textile azo dyes. Physico-chemical conditions have been optimized to achieve maximum decolorization.

\section{Materials and Methods}

\section{Dyes and Chemicals}

Four commonly used textile dyes, namely Reactive Yellow 180, Reactive Red 180, Reactive Red 198 and Red RR were procured from Jamara textile industry, Erode, Tamil Nadu, India. The dyes were initially studied for the absorption maxima in a UV-Vis spectrophotometer (UV-Vis 1800, Schimadzu, Japan) from 190-800nm. Nutrient broth (Peptone, $\mathrm{NaCl}$, Beef extract and Yeast extract) was obtained from Himedia Labs, Mumbai, India.

\section{Preliminary screening and identification of the novel isolate}

The textile effluent polluted soil was aseptically collected from CETP, Perundurai, Erode, Tamil Nadu, India. One gram of soil sample was added in $100 \mathrm{ml}$ of sterile distilled water and serially diluted by the standard protocol. From each dilution $100 \mu 1$ of sample was plated on nutrient agar medium and kept for incubation at $37^{\circ} \mathrm{C}$ for 24 hrs (Elisangela et al., 2009). Seven bacterial cultures (SI 01 to SI 07) were isolated based on the color, morphology and raised as pure culture on a slant containing nutrient agar for further studies. The organisms were used for decolorization studies after preculturing in nutrient broth $(\mathrm{g}$ $\mathrm{L}^{-1}$ ) at $37 \pm 2^{\circ} \mathrm{C}$ for $16-18 \mathrm{hrs}$ (log phase) under shaking condition at $\mathrm{pH}$ 7. All the seven isolates were inoculated individually on a dye Reactive Red 198 (chosen as a representative of azo dyes for primary decolorization efficiency test) containing medium and kept for incubation at $37^{\circ} \mathrm{C}$ for $72 \mathrm{hrs}$ both in shaking and static conditions. Based on the decolorization efficiency and abundance in preliminary screening (isolation experiments) SI 01 was chosen for testing decolorization efficiency on other 
dyes and was also subjected to identification through biochemical analysis.

\section{Optimization of culture conditions}

In order to figure out the optimal physicochemical parameters required for growth the novel isolate SI 01 was subjected to growth kinetics study for a period of 24 hours following standard procedure at different culture conditions such as $\mathrm{pH}(6,7,8$ and 9), Temperature $\left(30,37\right.$ and $\left.45^{\circ} \mathrm{C}\right)$, shaking and static conditions in nutrient broth.

\section{Testing decolorizing ability}

The decolorizing ability of the novel isolate SI 01 was tested individually on the four chosen azo dyes. Inoculum was used at $5 \%$ concentration when the Optical Density reached 1.0, in a $250 \mathrm{ml}$ Erlenmeyer flask containing $100 \mathrm{ml}$ nutrient broth with the dye concentration of $100 \mathrm{mg}^{-\mathrm{l}^{-1}}$ in both shaking $(120 \mathrm{rpm})$ and static conditions at $37^{\circ} \mathrm{C}$ for a period of $72 \mathrm{hrs}$. Further, a sequential aerobic and microaerophilic process was also carried out to study the decolourization efficiency, where the culture was first subjected to shaking condition (at $120 \mathrm{rpm}$ for first $24 \mathrm{hrs}$ ) followed by static condition up to $72 \mathrm{hrs}$ at $37^{\circ} \mathrm{C}$ in $\mathrm{pH} 8$ (Kalyani et al., 2009). All the experiments were performed in triplicates.

\section{Decolorization assay}

Decolorization was detected by UV-Vis spectrophotometer (Shimadzu UV-Vis Spectrophotometer, Japan) at respective $\lambda_{\max }$ using the supernatant from the liquid culture medium after centrifugation at $10,000 \mathrm{rpm}$ for ten minutes in a refrigerated centrifuge (5804R, Eppendorf, Germany). The removal of the color was reported as \% decolorization.

$\left[\%=\mathrm{A}_{0}-\mathrm{A}_{\mathrm{t}} / \mathrm{A}_{0} \mathrm{x} 100\right]$
Where $A_{0}$ and $A_{t}$ were absorbance of the dye solution initially and at cultivation time (t), respectively. Each decolorization value is a mean for three parallel experiments. Abiotic controls (without microorganisms) were also included (Senthil et al., 2016).

\section{Analysis of the decolorized product through UV-Vis spectral analysis}

The samples were collected before and after the decolorization processes and filtered through $0.2 \mu \mathrm{m}$ membrane filters. The filtrate was then scanned in the UV-Vis Spectrophotometer (Schimadzu UV-Vis 1800, Japan) within the range of $190-$ $1100 \mathrm{~nm}$. Appropriate blank was also subjected to the scanning process. The band width was set to $1 \mathrm{~nm}$ during the scanning program. The absorbance was noted at the respective characteristic peak area $\left(\lambda_{\max }\right)$ for the interpretation of results (Saratale et al., 2009b).

\section{Adsorption Desorption Assay}

Desorption studies were carried out to find out the extent of adsorbed color to the bacterial biomass during the process of color removal. Different desorbing agents like $1 \mathrm{~N}$ sodium hydroxide, $1 \mathrm{~N}$ Hydrochloric acid and double distilled water. Known volumes of thoroughly shaken samples were taken and centrifuged to obtain pellets. The pellets were then treated with above chemicals and extracted twice to remove the adsorbed color, till no more color could be extracted from the biomass. The extent of color adsorbed was estimated by comparing with the actual color of control and the color removed by the bacterial biomass. Controls of pure inocula in buffer, un-inoculated dyesamples/effluent and non-decolorizers were also run parallelly and subjected to the same desorption protocol, to eliminate any color being produced due to the intracellular 
contents of the bacteria and the chances of a false reading.

\section{Scanning electron microscopy}

The control (unexposed cells) and test samples were fixed with glutaraldehyde, dehydrated with a series of ethanol washes with progressively increasing the ethanol concentrations for $5 \mathrm{~min}$. Finally, the dehydrated samples were air-dried at room temperature and mounted on stainless steel SEM stubs, sputter coated with gold in an ion counter and examined under a scanning electron microscope to study the effect of dyes on the bacterial cell and its mechanism.

\section{Results and Discussion}

\section{Structure and absorption maxima of the dyes}

The four textile dyes chosen for this study were based on their frequent usage in textile industries and availability of structure in literatures. The absorption spectra of four dyes were studied (350 nm to $750 \mathrm{~nm}$ ) in a double beam UV-Vis Spectrophotometer. From the optical density at $1 \mathrm{~nm}$ bandwidth, the absorption maximum was determined and presented in Table 1.

\section{Preliminary Screening and optimization}

Seven different bacterial strains were isolated based on the colony morphology from the contaminated soil samples and were named as Soil Isolate 01 to Soil Isolate 07 (SI 01 to SI 07) based on abundance. Preliminary screening revealed that SI 01 demonstrated a maximum decolorization of $88.75 \%$ on Reactive Red 198 in 72 hours under static condition. Whereas the strain demonstrated maximum decolorization of $87.5 \%$ on reactive red 198 in 72 hrs under shaking condition which is insignificantly different. The isolate was then subjected to biochemical based identification and was found to be of genus Lysinibacillus. The biochemical characteristic of the strain is given in Table 2.

\section{Optimization studies}

As the Soil Isolate 01(Lysinibacillus sp.) was found to be the best decolorizing bacterial strain from preliminary screening on Reactive Red 198, it was subjected for growth kinetics studies in different conditions as mentioned earlier in the materials and methods. The Soil Isolate 01demonstrated better growth characteristics at $37^{\circ} \mathrm{C}$ in nutrient broth at $\mathrm{pH} 8.0$ incubated in the shaking condition (Data not shown).

\section{Decolorization under different culture conditions}

As the Soil Isolate 01demonstrated maximum growth at $\mathrm{pH} 8,37^{\circ} \mathrm{C}$ under shaking condition the same conditions were used for decolourization experiments. There was no significant decolourization in all the four dyes tested until $24 \mathrm{hrs}$ (Table 3, 4, 5 and 6). Similar to most of the bacterial decolourizations Soil Isolate 01was not able to decolorize the dye under aerobic (shaking) conditions effectively. Due to poor decolourization the incubation was extended to 48 and 72 hrs in both shaking and static conditions. The static (microaerophilic) condition was found to be optimal for decolorization. Microorganisms able to grow on dye containing medium under shaking condition, but not decolorize dyes under aerobic condition (Anliker 1979). However, cell growth was poor under static condition as compared to shaking condition. Reports indicate that oxygen is deleterious to the activity of enzyme (azoreductase) which is responsible for azo bond reduction, where as oxygen 
favors bacterial growth under shaking condition (Ogugbue et al., 2012).

A sequential aerobic and microaerophilic process which involved both shaking and static conditions was also performed to check decolourization efficiency of Soil Isolate 01in all the four dyes. From the result it could be inferred that the sequential aerobic and microaerophilic process (shaking and static) has increased the rate of decolorization and has reached its maximum within $48 \mathrm{hrs}$ in all the four dyes when compared to that of independent static and shaking conditions (Table 3,4,5 and 6). Our results were in accordance with the previous reports and indicate that the bacterial cultures under static condition were more efficient in decolorizing dyes used in textile industry. Ghodake et al., 2009 also reported decolorization rate of Direct Brown MR at static $91.3 \%$ and $59.3 \%$ under shaking condition. Similar kinds of results were reported in the previous studies in case of Psuedomonas SUK1 (Kalyani et al., 2009) and in case of Psuedomonas aeruginosa BCH (Jadhav et al., 2011).

\section{UV-Vis analysis and scanning electron microscopy}

The biodegradation of the four azo dyes was monitored by UV-Vis analysis. Experiments revealed that the Soil Isolate 01decolorized all the four azo dyes in such a way that its absorption peaks (Fig. 1, 2, 3 and 4) in the visible range disappeared while the absorption peak in the UV range did not diminish. Inspecting the cell mats also showed that Soil Isolate 01retained their natural color after decolorization of all the dyes. According to the literatures decolorization of dyes by bacteria could be due to adsorption by microbial cells, or to biodegradation. In the case of adsorption, the UV-Vis absorption peaks decrease approximately in proportion to each other, whereas in biodegradation, either the major visible light absorbance peak disappears completely, or a new peak appears (Fig 5). Dye adsorption can also be clearly judged by inspecting the cell mats. Cell mats become deeply colored because of the adsorbed dyes, whereas those retaining their original colors occur when biodegradation takes place. To observe the effect of decolorization of the textile dyes on the bacterial biomass and its mechanism, Scanning Electron Microscopy was carried out. The surfaces of the cells exposed to dyes were as smooth as seen in the unexposed control cells (Fig 6 a, b). This would mean that biodegradation could be a major contributor to color removal rather mere adsorption. Studying live versus inactivated cells proved that only live bacterial cells were able to decolorize the dye whereas inactivated cells were unable to do so. This proved that decolorization was not due to physical adsorption by inactivated cells. The novel strain (SI 01) isolated from the textile effluent polluted soil rapidly decolourized all the chosen four azo dyes under sequential aerobic and microaerophilic conditions, with differences in decolourization times depending on the dye structure, as was confirmed by the UVvis analysis. The study reveals that decolourization was strongly dependent on the biomass size in the medium, indicating the need for shaking conditions (aerobic) during decolourization process. High decolourization efficiency was attained in shorter duration under sequential static condition when compared to that of shaking and static conditions separately. Although this bacterium has shown greater dye degradation ability as compared to other bacteria, there is no much available literature on dye decolourization with Lysinibacillus sps. 
Table.1 Adsorption maxima of the chosen four textile azo dyes. $\neg$

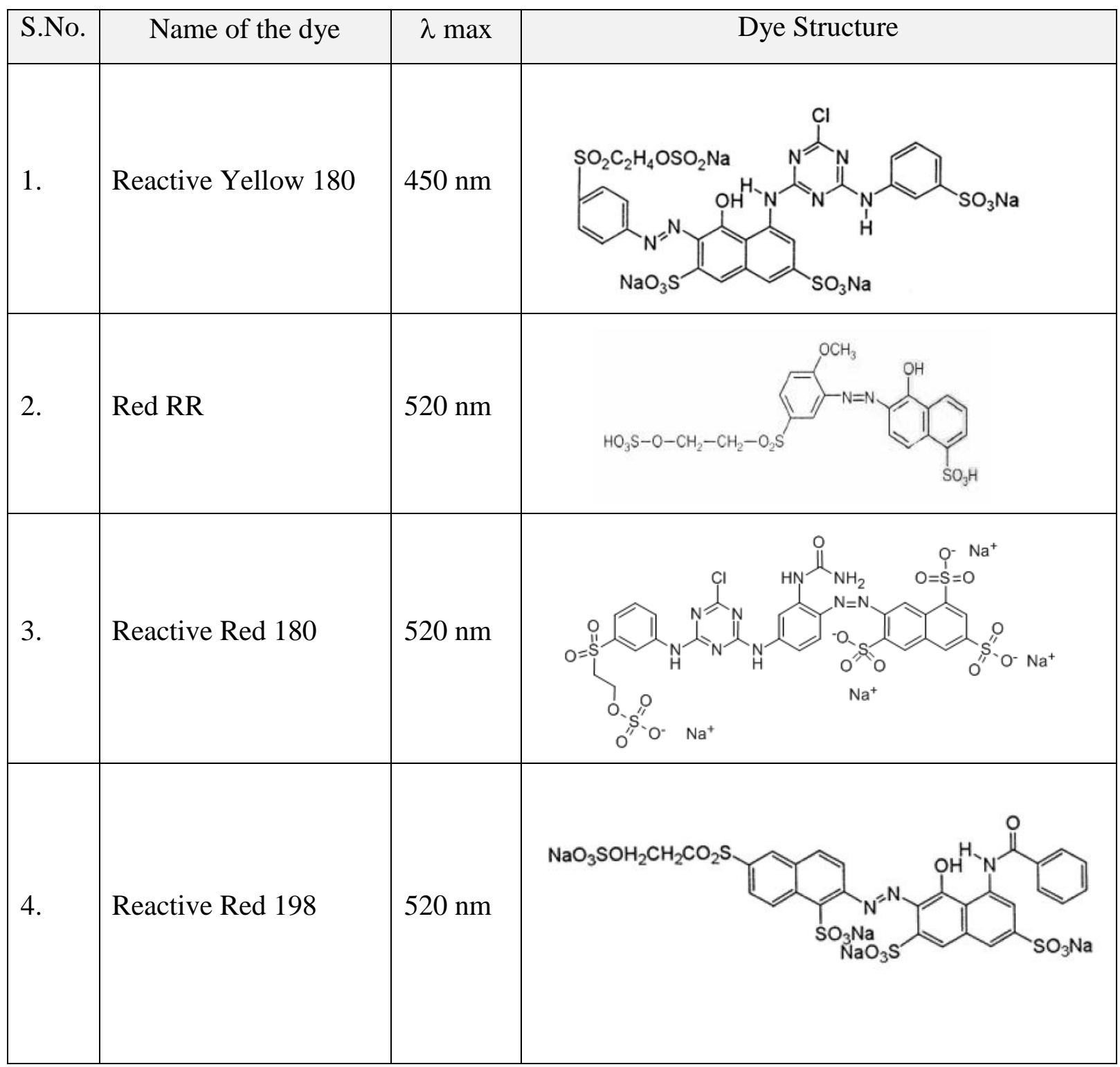


Table.2 Colony morphology and biochemical characteristics of the novel Soil Isolate SI 01.

\begin{tabular}{|c|c|c|c|}
\hline Sl. No. & \multicolumn{2}{|c|}{ Tests Performed } & Results \\
\hline 1. & \multicolumn{2}{|c|}{$\begin{array}{l}\text { Colony morphology on } \\
\text { Nutrient Agar }\end{array}$} & $\begin{array}{l}\text { Opaque, unpigmented and } \\
\text { smooth colonies }\end{array}$ \\
\hline 2. & \multicolumn{2}{|c|}{ Gram stain } & Positive \\
\hline 3. & \multicolumn{2}{|l|}{ Haemolysis } & Non-haemolytic \\
\hline 4. & \multicolumn{2}{|l|}{ Motility } & Motile \\
\hline 5. & \multirow{3}{*}{$\begin{array}{l}\text { Sugar } \\
\text { Utilization }\end{array}$} & Glucose & Positive \\
\hline 6. & & Lactose & Negative \\
\hline 7. & & Sucrose & Positive \\
\hline 8. & \multicolumn{2}{|c|}{$\mathrm{H}_{2} \mathrm{~S}$ Production } & Negative \\
\hline 9. & \multicolumn{2}{|l|}{ Urease Test } & Negative \\
\hline 10. & \multicolumn{2}{|l|}{ IMViC Test } & Negative \\
\hline 11. & \multicolumn{2}{|c|}{ Nitrate Reduction } & Positive \\
\hline 12. & \multicolumn{2}{|c|}{ Phenylalanine } & Positive \\
\hline 13. & \multicolumn{2}{|c|}{ Casein hydrolysis } & Positive \\
\hline 14. & \multicolumn{2}{|c|}{ Citrate utilization } & Positive \\
\hline 15. & \multicolumn{2}{|c|}{ Tween 20 hydrolysis } & Positive \\
\hline 16. & \multicolumn{2}{|c|}{ Oxidase } & Positive \\
\hline 17. & \multicolumn{2}{|l|}{ Catalase } & Positive \\
\hline 18. & \multicolumn{2}{|c|}{ Starch Hydrolysis } & Positive \\
\hline 19. & \multicolumn{2}{|c|}{ Gelatine Hydrolysis } & Positive \\
\hline 20. & \multicolumn{2}{|c|}{ Huge-Leifsion } & Oxidative \\
\hline
\end{tabular}

Table.3 Decolourization efficiency of Soil Isolate 01 on Reactive Yellow 180 dye under shaking, static and sequential aerobic and microaerophilic process conditions.

\begin{tabular}{|l|l|l|l|}
\hline $\begin{array}{l}\text { Duration } \\
\text { in Hrs }\end{array}$ & $\begin{array}{l}\text { \% of the } \\
\text { Decolorization } \\
\text { under Shaking } \\
\text { condition }\end{array}$ & $\begin{array}{l}\text { \% of the Decolorization } \\
\text { under static condition }\end{array}$ & $\begin{array}{l}\text { \% of the Decolorization under Sequential } \\
\text { aerobic and microaerophilic process } \\
(24 \text { hrs shaking followed by static } \\
\text { condition upto 72 hrs) }\end{array}$ \\
\hline $24 \mathrm{hrs}$ & $6.34 \pm 1.6 \%$ & $35.17 \pm 5.3 \%$ & $5.26 \pm 4.0 \%$ \\
\hline $48 \mathrm{hrs}$ & $37.02 \pm 4.2 \%$ & $50.62 \pm 2.1 \%$ & $86.84 \pm 1.6 \%$ \\
\hline $72 \mathrm{hrs}$ & $60.43 \pm 1.8 \%$ & $85.58 \pm 1.9 \%$ & $86.84 \pm 2.6 \%$ \\
\hline
\end{tabular}

Table.4 Decolourization efficiency of Soil Isolate 01 on Reactive Red RR dye under shaking, static and sequential aerobic and microaerophilic process conditions

\begin{tabular}{|l|l|l|l|}
\hline $\begin{array}{l}\text { Duration } \\
\text { in Hrs }\end{array}$ & $\begin{array}{l}\text { \% of the Decolorization } \\
\text { under Shaking condition }\end{array}$ & $\begin{array}{l}\% \text { of the } \\
\text { Decolorization } \\
\text { under static } \\
\text { condition }\end{array}$ & $\begin{array}{l}\text { \% of the Decolorization under Sequential } \\
\text { aerobic and microaerophilic process } \\
\text { (24 hrs shaking followed by static condition } \\
\text { upto 72 hrs) }\end{array}$ \\
\hline $24 \mathrm{hrs}$ & $10.45 \pm 2.4 \%$ & $25.36 \pm 4.2 \%$ & $13.75 \pm 2.2 \%$ \\
\hline $48 \mathrm{hrs}$ & $34.81 \pm 2.5 \%$ & $45.28 \pm 1.8 \%$ & $85 \pm 3.1 \%$ \\
\hline $72 \mathrm{hrs}$ & $67.04 \pm 1.5 \%$ & $85.22 \pm 1.6 \%$ & $86.25 \pm 3.5 \%$ \\
\hline
\end{tabular}


Table.5 Decolourization efficiency of Soil Isolate 01 on Reactive Red 180 dye under shaking, static and sequential aerobic and microaerophilic process conditions

\begin{tabular}{|l|l|l|l|}
\hline $\begin{array}{l}\text { Duration } \\
\text { in Hrs }\end{array}$ & $\begin{array}{l}\text { \% of the } \\
\text { Decolorization under } \\
\text { Shaking condition }\end{array}$ & $\begin{array}{l}\text { \% of the } \\
\text { Decolorization } \\
\text { under static } \\
\text { condition }\end{array}$ & $\begin{array}{l}\text { \% of the Decolorization under Sequential } \\
\text { aerobic and microaerophilic process } \\
\text { (24 hrs shaking followed by static } \\
\text { condition upto 72 hrs) }\end{array}$ \\
\hline $24 \mathrm{hrs}$ & $6.98 \pm 2.6 \%$ & $12.36 \pm 1.4 \%$ & $7.14 \pm 0.9 \%$ \\
\hline $48 \mathrm{hrs}$ & $29.32 \pm 1.5 \%$ & $35.69 \pm 1.5 \%$ & $80.61 \pm 1.6 \%$ \\
\hline $72 \mathrm{hrs}$ & $50 \pm 1.7 \%$ & $88.88 \pm 2.8 \%$ & $90.81 \pm 1.9 \%$ \\
\hline
\end{tabular}

Table.6 Decolourization efficiency of Soil Isolate 01 on Reactive Red 198 dye under shaking, static and sequential aerobic and microaerophilic process conditions

\begin{tabular}{|l|l|l|l|}
\hline $\begin{array}{l}\text { Duration in } \\
\text { Hrs }\end{array}$ & $\begin{array}{l}\text { \% of the Decolorization } \\
\text { under Shaking condition }\end{array}$ & $\begin{array}{l}\text { \% of the } \\
\text { Decolorization } \\
\text { under static } \\
\text { condition }\end{array}$ & $\begin{array}{l}\text { \% of the Decolorization under } \\
\text { Sequal aerobic and } \\
\text { (24 hrs shaking followed by static } \\
\text { condition upto } 72 \text { hrs })\end{array}$ \\
\hline $24 \mathrm{hrs}$ & $42.5 \pm 1.9 \%$ & $33.75 \pm 3.2 \%$ & $25 \pm 2.7 \%$ \\
\hline $48 \mathrm{hrs}$ & $87.5 \pm 2.4 \%$ & $85 \pm 4.1 \%$ & $85 \pm 4.8 \%$ \\
\hline $72 \mathrm{hrs}$ & $87.5 \pm 3.4 \%$ & $88.75 \pm 3.7 \%$ & $85 \pm 3.1 \%$ \\
\hline
\end{tabular}

Fig.1 Spectral analysis of Reactive Yellow 180: a - native dye, b - after biological treatment

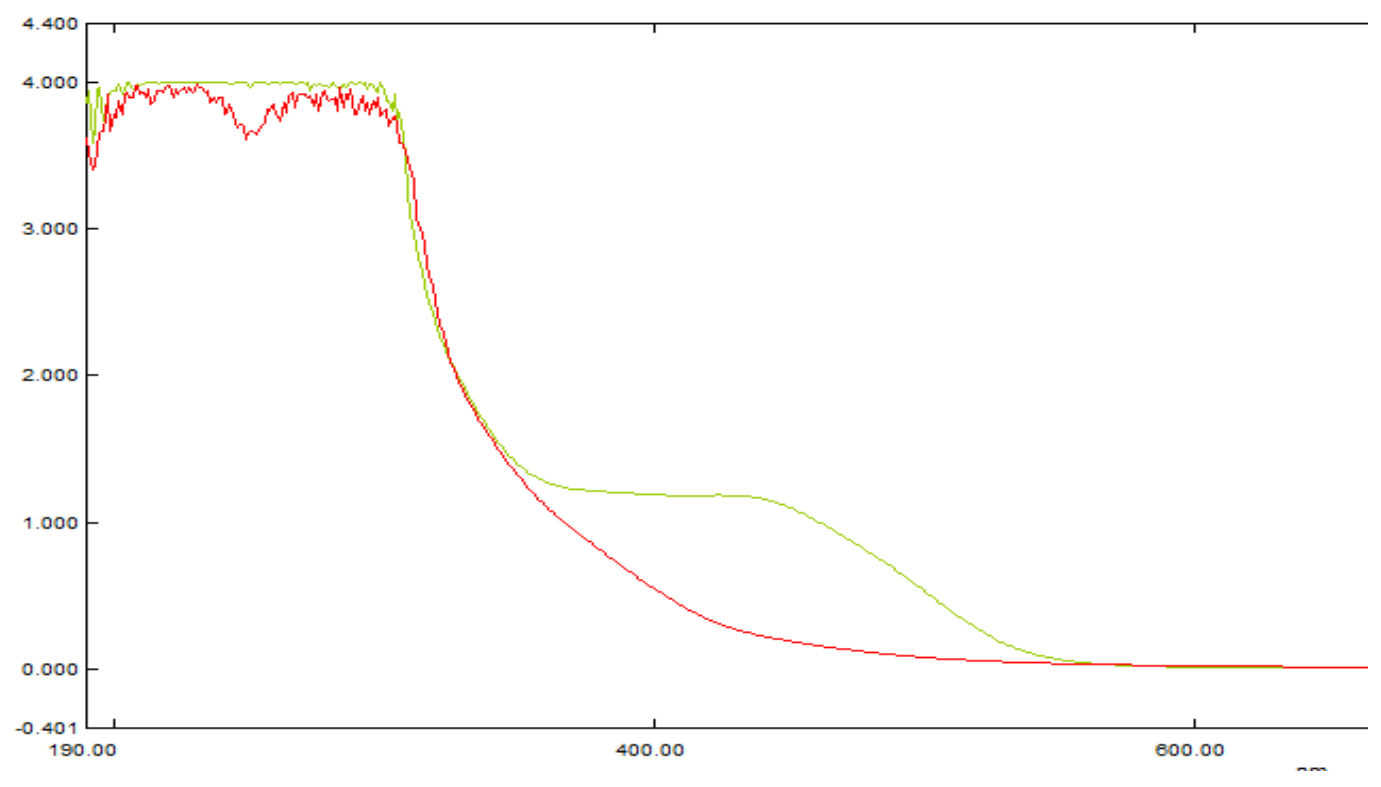


Fig.2 Spectral analysis of Red RR: a - native dye, b - after biological treatment.

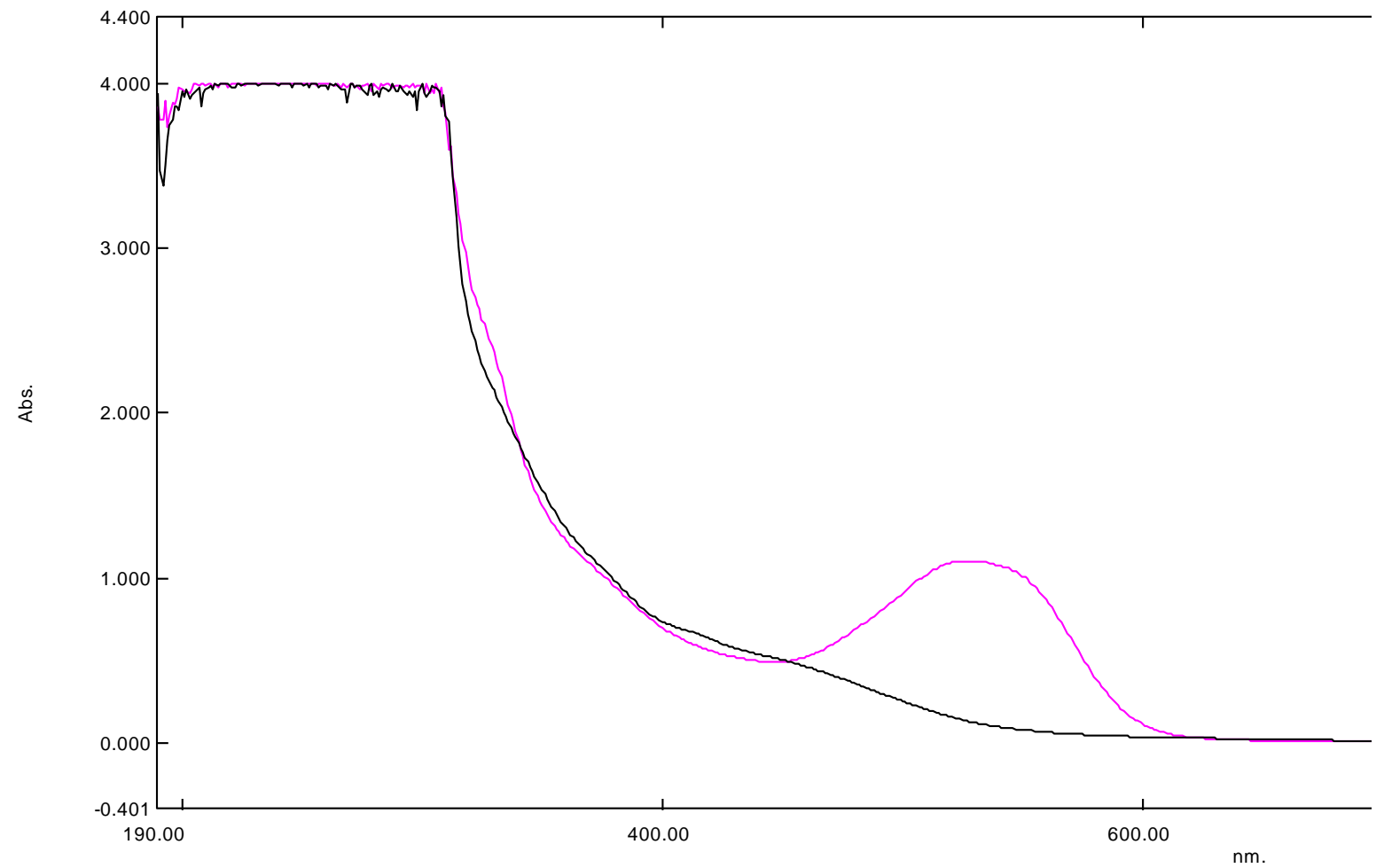

Fig.3 Spectral analysis of Reactive Red 180: a - native dye, b - after biological treatment.

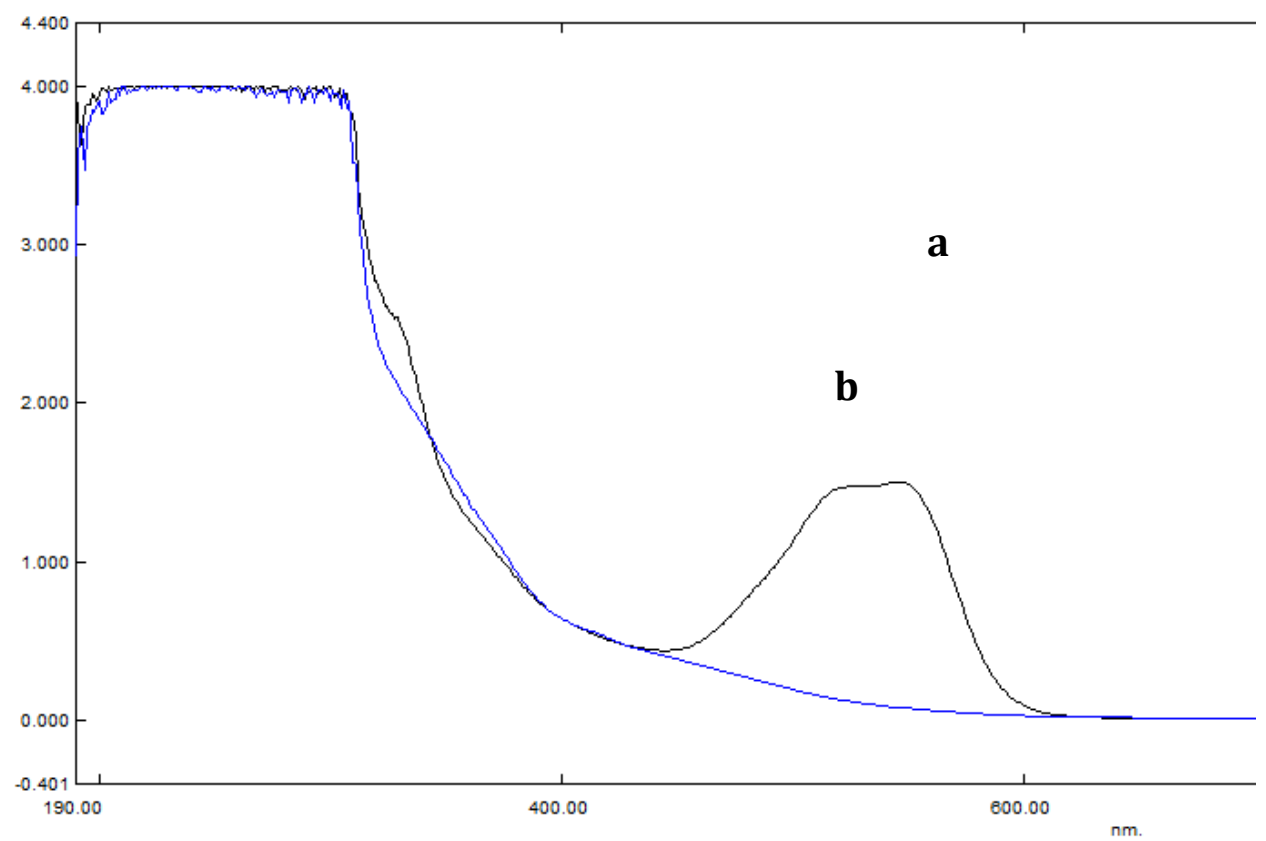


Fig.4 Spectral analysis of Reactive Red 198: a - native dye, b - after biological treatment.

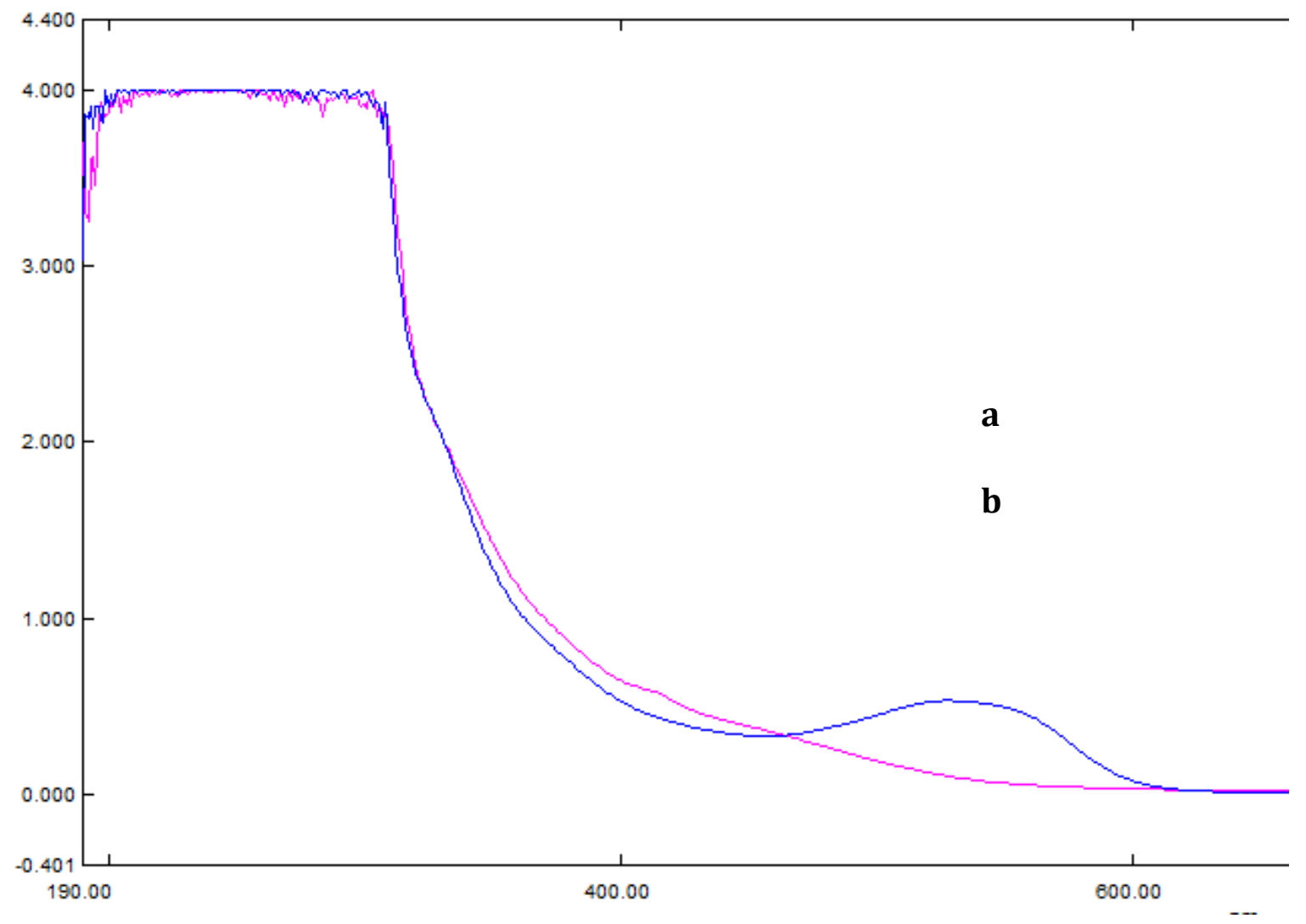

Fig.5 Spectral analysis of the Adsorption - Desorption Assay of the Isolate SI 01

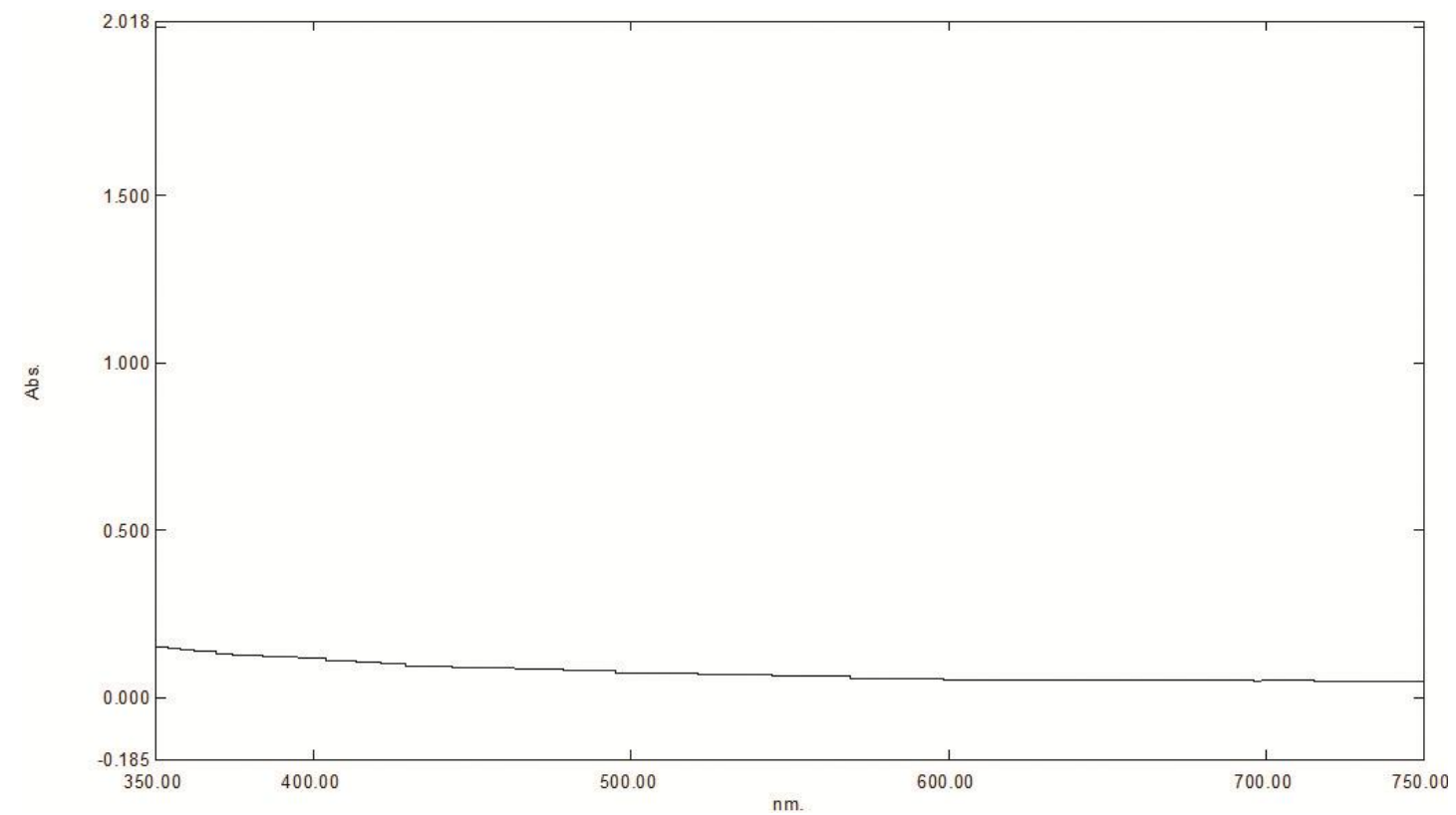


Fig.6 Scanning Electron Micrograph of the Soil Isolate 01; A - before decolorization (unexposed cells); B- after decolorization (exposed cells)

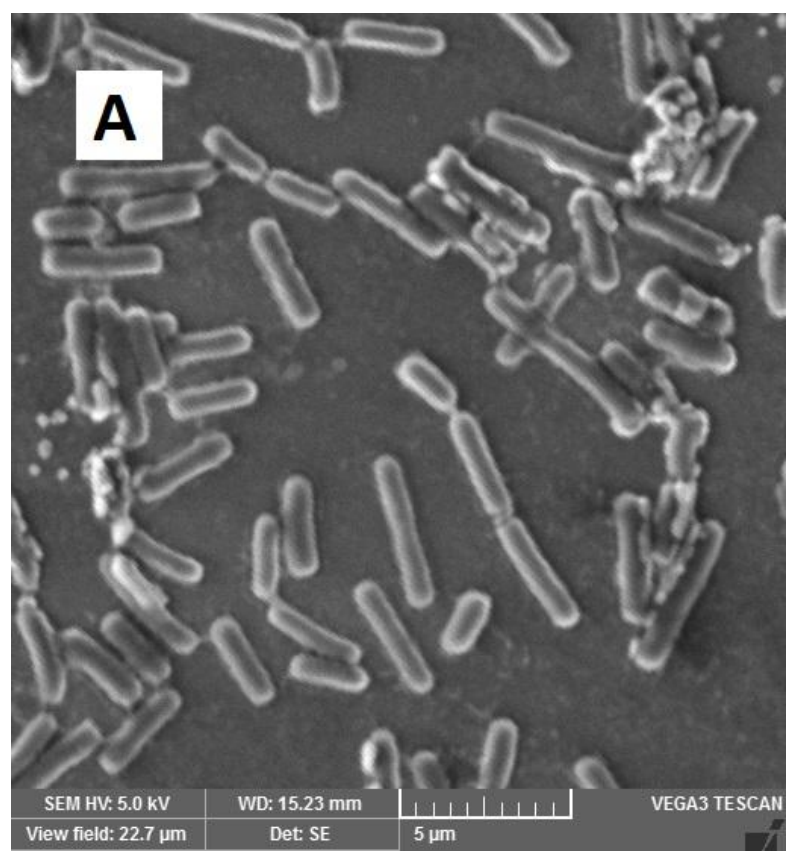

Azoreductase is the key enzyme responsible for the reductive azo dye degradation in bacterial species. The presence of oxygen normally inhibits the azo bond reduction activity, since aerobic respiration may dominate use of the NADH, thus impeding electron transfer from $\mathrm{NADH}$ to the azo bond. The advantage of the anaerobic reduction of azo dyes is that oxygen depletion is easily accomplished in microaerophilic cultures thus enabling anaerobic, facultative anaerobic and microaerophilic bacteria to reduce azo dyes. It is evident from the present study as the decolourization was not significant when maintained in shaking condition. However, the precise mechanism of anaerobic azoreduction is still not totally understood. It was recently suggested that microbial anaerobic azoreduction was linked to the electron transport chain, and that dissimilatory azoreduction was a form of microbial anaerobic respiration. In addition, different models for the nonspecific

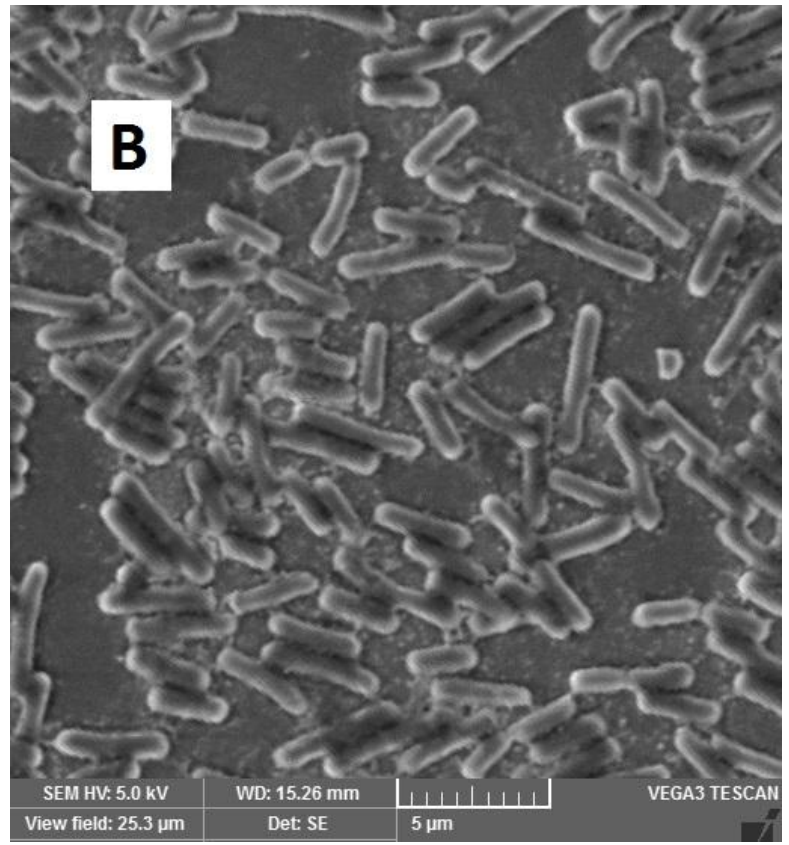

reduction of azo dyes by bacteria, which do not require transport of the azo dyes or reduced flavins through the cell membrane, or that describe the extracellular reduction of azo dyes by anaerobic bacteria, were recently suggested. These results suggested that azo dye reduction was a strain-specific mechanism that could be performed by an azoreductase enzyme or by a more complex metabolic pathway. Thus, due to the lack of information about the metabolism of Lysinibacillus the usual true time dependant kinetic determinations of the azoreductase activity using the azo dye as substrate were not performed, and the azo reduction mechanism of this novel Soil Isolate 01(Lysinibacillus) will be the subject of a future specific study. This methodology using a single microorganism in a sequential aerobic - microaerophilic process was shown to be very effective in azo dye decolourization. In a single reactor with a single bacterium, only changing the agitation conditions, it is possible not only to 
decolorize the dyes, but also to achieve a good degree of mineralization and low toxicity, with low running and maintenance costs.

\section{Acknowledgement}

The authors gratefully acknowledge and sincerely thank the University Grants Commission (UGC), New Delhi for the financial support provided for this research work through MRP scheme [F. No. $43-$ 134/2014 (SR)]. The authors sincerely acknowledge the Principal and the Management of National College, for their constant support in pursuing this research.

\section{References}

Anliker, R., 1979. Ecotoxicology of dyestuffs a joint effort by industry. Ecotoxicol Environ Saf.3, 59-74. doi:10.1016/0147-6513(79)90060-5

Chang, J.S., B.Y. Chen, and Lin, Y.S. 2004. Stimulation of bacterial decolorization of an azo dye by extracellular metabolites from Escherichia coli strain NO3. Bioresour. Technol. 91, 243-248.

Elisangela, F., Z. Andrea, D.Fabio, R.D.M. Cristiano, D.L. Regina, and Artur, C.P. 2009. Biodegradation of textile azo dyes by a facultative Staphylococcus arlettae strain VN-11 using a sequential microaerophilic/ aerobic process. Int Biodeterior Biodegrad. 63:280-288. doi:10.1016/j.ibiod.2008.10.003

Ghodake, G., S. Jadhav, V. Dawkar, and Govindwar, S.P. 2009. Biodegradation of diazo dye Direct brown MR by Acinetobacter calcoaceticus NCIM 2890. Int Biodeterior Biodegrad. 63: 433-439.

doi:10.1016/j.ibiod.2008.12.002

Jadhav, J.P., D.C. Kalyani, A.A. Telke, S.S Phugare, and Govindwar, S.P. 2010. Evaluation of the efficacy of a bacterial consortium for the removal of color, reduction of heavy metals, and toxicity from textile dye effluent. Bioresource Technol. 101:165-173. doi:10.1016/j.biortech.2009.08.027

Jadhav, S.B., S.S. Phugare, P.S. Patil, and Jadhav, J.P. 2011. Biochemical degradation pathway of textile dye Remazol red and subsequent toxicological evaluation by cytotoxicity, genotoxicity and oxidative stress studies. Int Biodeterior Biodegrad. 65:733-743. doi:10.1016/j.ibiod.2011.04.003

Kalyani,D.C., A.A. Telke, R.S. Dhanve, and Jadhav, J.P .2009. Ecofriendly biodegradation and detoxification of reactive red 2 textile dye by newly isolated Pseudomonas sp. SUK1. J, Hazard Mater. 163:735-742. doi:10.1016/j.jhazmat.2008.07.020

Khouni, I. B. Marrot, Moulin and Amar, R.B. 2011. Decolourization of the reconstituted textile effluent by different process treatments: enzymatic catalysis, coagulation/flocculation and nanofiltration processes. Desalination. 268:27-37. doi:10.1016/j.desal.2010.09.046

Manai, I., B .Miladi, A.E. Mselmi, I. Smaali, A. Hassen, M. Hamd, and Bouallagui, H. 2016. Industrial textile effluent decolourization in stirred and static batch cultures of a new fungal strain Chaetomium globosum IMA1 KJ472923. J Environ Manag 170:8-14. doi:10.1016/j.jenvman.2015.12.038

Mendez-Martineza, A.J., M.M. DavilaJimeneza, O. Ornelas-Davilab, M.P. Elizalde- Gonzalezb, U. Arroyo-Abadb, I. Sires, and Brillas, E. 2012. Electrochemical reduction and oxidation pathways for Reactive Black 5 dye using nickel electrodes in divided and undivided cells. Electrochim Acta. 
59:140-149.

doi:10.1016/j.electacta.2011.10.047

Ogugbue, C.J., T. Sawidis, and Oranusi, N.A. 2012. Bioremoval of chemically different synthetic dyes by Aeromonas hydrophila in simulated wastewater containing dyeing auxiliaries. Annals of Microbiology . 62:1141-1152. doi:10.1007/s 13213-011-0354-y

Parshetti, G.K., S.D. Kalme, S.S Gomare, and Govindwar S.P. (2007) Biodegradation of reactive blue-25 by Aspergillus ochraceus NCIM-1146. Bioresource Technol. 98:3638-3642. doi: 10.1016/j.biortech.2006.11.017

Saratale, R.G., G.D. Saratale, D.C. Kalyani, J.S. Chang, and Govindwar, S.P. 2009. Enhanced decolorization and biodegradation of textile azo dye Scarlet R by using developed microbial consortium-GR. Bioresour Technol. 100:2493-2500.

doi:10.1016/j.biortech.2008.12.013

Saratale, R.G., G.D. Saratale, J.S. Chang, and Govindwar, S.P. 2009. Decolorization and biodegradation of textile dye Navy blue HER by Trichosporon beigelii NCIM-3326. J Hazard Mater. 166:1421-1428. doi:10.1016/j.jhazmat.2008.12.068

Senthil Kumar, S., S. Shantkriti, T. Muruganandham, E. Murugaesh, R. Niraj, and Govindwar, S.P. 2016. Bioinformatics aided microbial approach for bioremediation of wastewater containing textile dyes. Ecol
Inform.

$31: 112-121$ doi:10.1016/j.ecoinf.2015.12.001

Tan, L., M. He, L. Song, Fu, and Shi, S. 2016. Aerobic decolorization, degradation and detoxification of azo dyes by a newly isolated salt-tolerant yeast Scheffersomyces spartinae TLHSSF1. Bioresour Technol. 203: 287-294. doi:10.1016/j.biortech.2015.12.058

Verma, A.K., R.R. Dash,. and Bhunia, P. 2012. A review on chemical coagulation flocculation technologies for removal of colour from textile wastewaters. J Environ Managua 93:154-168. doi:10.1016/j.jenvman.2011.09.012

Waghmode, T.R., M.B. Kurade and Govindwar, S.P. 2011. Time dependent degradation of mixture of structurally different azo and non azo dyes by using Galactomyces geotrichum MTCC 1360. Inter Biodeterior Biodegrad. 65:479486. doi:10.1016/j.ibiod.2011.01.010

Xu, M., J. Guo, X. Kong, Chen, and Sun, G. 2007. Fe(III)- enhanced azo reduction by Shewanella decolorationis S12. Appl Microbiol Biotechnol. 74:13421349. Doi:10.1007/s00253-006-0773-z

Yu Z., X. Zhou, Y. Wang, G.Yang, and Zhou, S. 2015. Dissimilatory Azoreduction of Orange I by a Newly Isolated Moderately Thermophilic Bacterium, Novibacillus thermophilus SG-1. Biotechnol Bioprocess Eng. 20:1064-1070. doi:10.1007/s12257015-0365-9.

\section{How to cite this article:}

Muruganantham, T., and Senthil Kumar, S. 2016. Effective Decolourization of Textile Azo Dyes by a Novel Bacterial Isolate Lysinibacillus SI 01 through Sequential Aerobic Microaerophilic Process. Int.J.Curr.Microbiol.App.Sci. 5(10): 1010-1022. doi: http://dx.doi.org/10.20546/ijcmas.2016.510.107 